\title{
Similar Device Architectures for Inverted Organic Solar Cell and Laminated Solid-State Dye-Sensitized Solar Cells
}

\author{
Ishwor Khatri, Jianfeng Bao, Naoki Kishi, and Tetsuo Soga \\ Department of Frontier Materials, Nagoya Institute of Technology, Nagoya 4668555, Japan \\ Correspondence should be addressed to Ishwor Khatri, ishwor_nep2000@yahoo.com \\ Received 14 April 2012; Accepted 28 May 2012 \\ Academic Editors: M. Hopkinson and A. Robinson
}

Copyright () 2012 Ishwor Khatri et al. This is an open access article distributed under the Creative Commons Attribution License, which permits unrestricted use, distribution, and reproduction in any medium, provided the original work is properly cited.

\begin{abstract}
Here, we examine the device architecture of two different types of solar cells mainly inverted organic solar cells and solid state dye-sensitized solar cells (DSSCs) that use organic materials as hole transportation. The inverted organic solar cells structure is dominated by work on titanium dioxide $\left(\mathrm{TiO}_{2}\right)$ and zinc oxide $(\mathrm{ZnO})$. These layers are sensitized with dye in solid state DSSCs. Because of the similar device architecture, it becomes possible to fabricate laminated solid-state DSSCs. The performance of the device was improved by varying the top metal electrode. In laminated solid-state DSSC, we expect that excited dye molecules inject electron into the conduction band of nanocrystalline $\mathrm{TiO}_{2}$ layer, whereas $\mathrm{P} 3 \mathrm{HT}$ provides efficient hole transportation. These solar cells are promising for future energy source as they are cheaper, light weight, flexible and made into large areas, which are showing growing importance.
\end{abstract}

\section{Introduction}

Organic photovoltaic (OPV) provides promise of a low-cost solar photovoltaic solution and attracts significant academic and industry research. Organic semiconducting materials having delocalized pi $(\pi)$ electron system can absorb sunlight, create exciton, and transport photogenerated charge carriers. They have higher absorption coefficients; therefore active layer of a few hundreds of nanometer range is enough. Electronic band gap of the materials can be controlled by chemical synthesis. Polymer-fullerene bulk heterojunction was studied showing several breakthroughs in efficiency [13]. Every year new record on power conversion efficiency (PCE) of organic solar cell is being set. Mitsubishi Chemical reportedly set a new efficiency record, producing organic solar cells with $9.2 \%$ conversion efficiency. Meanwhile, Konarka Technologies, Solarmer Energy Inc., and Heliatek are now reporting cells with efficiencies greater than $8 \%$ [4]. These results pave towards commercialization of the techniques. It is predicted that OPVs devices achieve 10\% efficiency from single layer device and around 15\% in tandem structure [5]. However, the conventional device architecture which consists of a poly(3,4-ethylenedioxythiophene):poly(styrenesulfonate) (PEDOT:PSS) as holecollecting layer and a bulk-heterojunction layer (polymerfullerenes), sandwiched between indium-doped tin oxide (ITO) or fluorine-doped tin oxide (FTO), and a low work function metal electrode is considered not efficient for higher power conversion efficiency and long stability. The low work function metal electrode can be easily oxidized in air leading to deterioration in performance. To address these problems, a new device architecture using a titanium oxide $\left(\mathrm{TiO}_{x}\right)$ or zinc oxide $(\mathrm{ZnO})$ buffer layer between the organic active layer and ITO substrate has been introduced as a hole blocking and oxygen barrier layer for device stability. Therefore, the concept of inverted organic solar cell was introduced [6-9].

\section{Inverted Solar Cell}

The name "inverted" describes the reversed change in polarity of solar cell. For example, in ITO/PEDOT:PSS/ P3HT:PCBM/Al device structure, ITO and Al electrodes collect holes and electrons, respectively, as shown in Figure 1(a). 


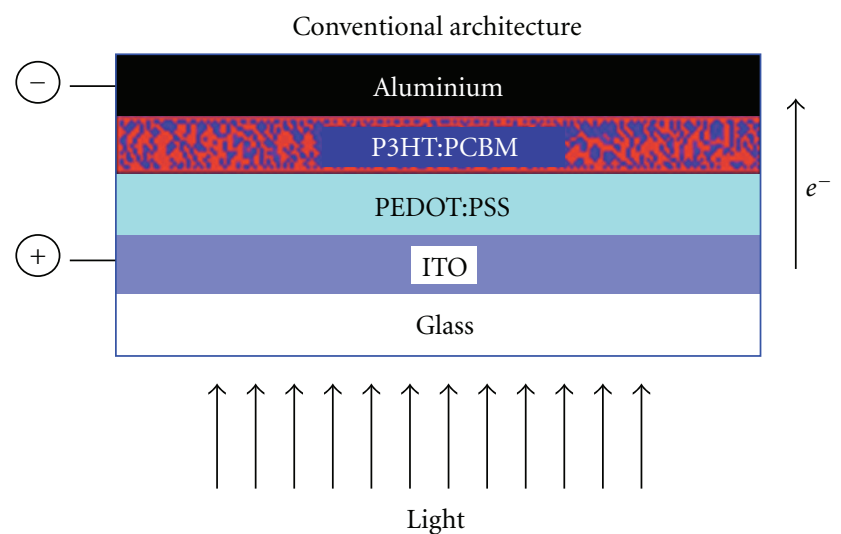

(a)

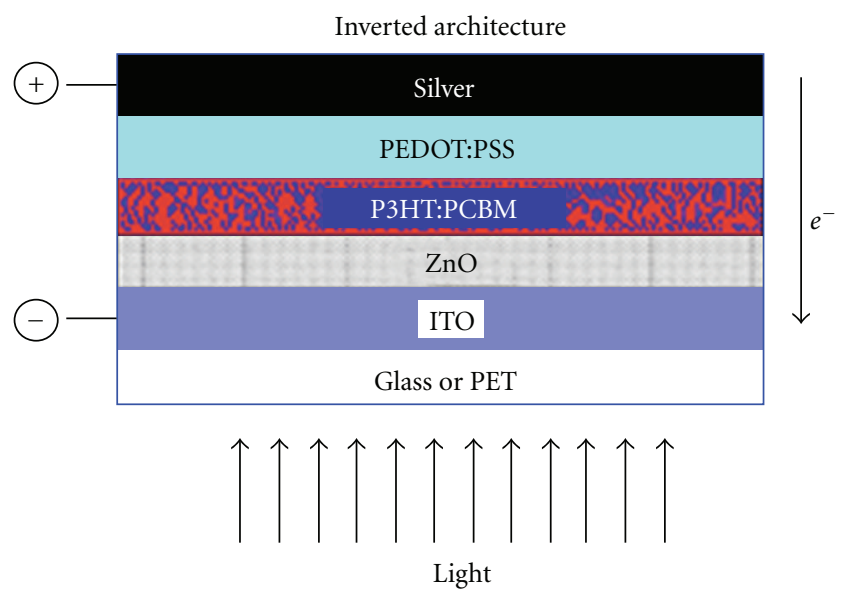

(b)

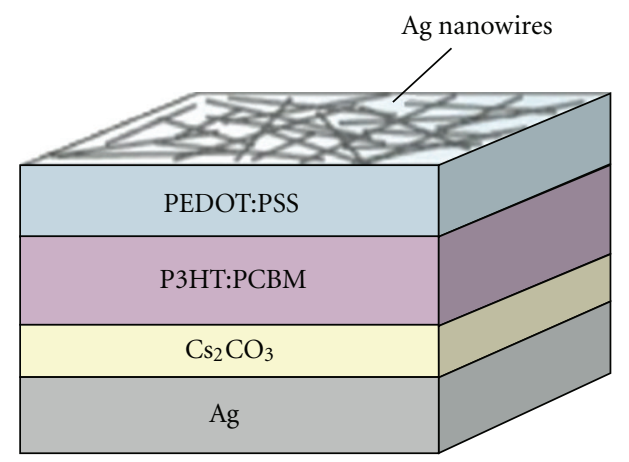

(c)

FIGURE 1: (a) Conventional device architecture of organic photovoltaic solar cell comprises spin-coated PEDOT:PSS and P3HT-PCBM layers and evaporated aluminium. (b) The inverted architecture employed spin-coated ZnO, P3HT-PCBM and PEDOT:PSS and evaporated silver [35]. (c) Fully solution-processed top illuminated inverted polymer solar cell on Ag plate comprises spin-Coated $\mathrm{Cs}_{2} \mathrm{Co}_{3}, \mathrm{P}_{3} \mathrm{HT}-\mathrm{PCBM}$, PEDOT:PSS and laminated Ag nanowires.

But in inverted device structure, proper $\mathrm{n}$ or $\mathrm{p}$-type interfacial layers are introduced above ITO or below metal electrode, which change the polarity of the device. Now, ITOs collect electrons and metal electrodes collect holes. In this way, the polarity of the solar cell is reversed. Schematic diagram of inverted solar cell is given in Figure 1(b). Higher work function metal electrodes like gold $(\mathrm{Au})$, silver $(\mathrm{Ag})$, and copper $(\mathrm{Cu})$ are generally used as top metal electrodes in inverted solar cell architecture. These metal electrodes are air-stable and make good contact with organic layers. Furthermore, nonvacuum coating technique process of top electrode is also possible [10-13], which is very important to reduce the device fabrication complexity and cost. Highenergy band gap materials such as zinc oxide $(\mathrm{ZnO})$ [14, 15], titanium oxide $\left(\mathrm{TiO}_{x}\right)$ [16-18], cesium carbonates $\left(\mathrm{Cs}_{2} \mathrm{CO}_{3}\right)[19,20]$, and calcium $(\mathrm{Ca})$ [21] are generally 
coated on ITO substrate for efficient electron transportation, whereas molybdenum trioxide (VI) $\mathrm{MnO}_{3}$ [22-26], vanadium oxide $\left(\mathrm{V}_{2} \mathrm{O}_{5}\right)[27,28]$, tungsten oxide $\left(\mathrm{WO}_{3}\right)[29,30]$, and solution-processed conducting polymer poly(3,4-ethylenedioxythiophene) poly(styrenesulfonate) (PEDOT:PSS) [31-33], sulfonated poly(diphenylamine) (SPDPA) [34] are deposited or coated below the top metal electrodes. Such interfacial layers play important roles (a) to suppress contact resistance between the organic and charge collecting electrodes [14-34], (b) change non-Ohmic contact to Ohmic contact [19], and (c) efficiently transport charges [14-35], and so on.

Furthermore, the inverted solar cell structures are classified into two categories. Figures $1(\mathrm{~b})$ and 1(c) are the two examples of inverted solar cell architecture introduced by Krebs et al. [35] and Gaynor et al. [11]. In the formal case, light is illuminated from the bottom electrode whereas it is illuminated from top in the latter case. Based on the light source illumination, the inverted architecture is differentiated into top illuminated or bottom illuminated inverted solar cells. The top illuminated architecture utilizes a reflective buried bottom electrode and a semitransparent top electrode (like Ag nanowires in Figure 1(c)) whereas the bottom illuminated inverted solar cell utilizes a higher work function reflective electrode at the top and semitransparent conducting electrode (like ITO, FTO) at the bottom (Figure 1(b)). In top illuminated inverted solar cell, it is important to note that the bottom electrode is metal foil instead of a glass substrate. $\mathrm{Ag}, \mathrm{ITO}, \mathrm{Cs}_{2} \mathrm{CO}_{3}, \mathrm{Al}$ are generally deposited in the metal foil to harvest light from reflection. The detail review on inverted polymer solar is given in [36].

\section{Laminated Polymer Solar Cell}

Inverted polymer solar cell architecture is an efficient way to improve the efficiency as well as stability of organic solar cells. It can be further simplified by stamping or laminating top metal electrodes for roll-to-roll fabrication [37-40]. It has been suggested that direct vacuum evaporation of the metal electrodes on the active polymeric layer could damage the surface morphology of the device reducing device performance [41-46]. Therefore, stacking [37-40] or stamping [47-51] processes are introduced to fabricate the device. Stacking or stamping as a method of device fabrication has several advantages over conventional-bottom up device fabrication process. They are (a) PCE of the stacking (or laminated) device which is almost similar or higher to the devices fabricated from the evaporated top metal electrode [37-40]. (b) Laminated interface produces Ohmic contact to another layer showing high fill factor and low series resistance [39]. (c) The processing step of thermal evaporation of a metal onto the active layer is eliminated which reduces the high parasitic resistance $[37,38]$. (d) Inert atmosphere for the fabrication of device is not necessary [3740]. (e) The device is self-encapsulated and mechanically protected from both sides [39]. (f) The methodology allows one to prepare, optimize, and characterize two parts of the device independently before bringing them to contact
[37-40]. (g) All solution processing fabrication of device is possible. (h) It is cost effective and simple method, which allows the fabrication of multijunction solar cell [37].

One way to fabricate multijunction solar cell is by connecting two polymer blend layers with introduction of a (semi) transparent metal or semiconducting layer between the blend layers, which is generally named as tandem solar cell. In tandem structure, the intermediate layer works as charge recombination center; therefore the device has an open circuit voltage $\left(V_{\text {oc }}\right)$ that is the sum of the values of two devices, whereas short circuit $\left(J_{\mathrm{sc}}\right)$ of the device is restricted to the smaller value of the two. On the other hand, in multilayer device, the two active layers are stacked directly (i.e., without any interfacial layer). Thus the device has a $J_{\text {sc }}$ value that is the sum of the values of the two cells. Recently, Sun et al. [52] demonstrated the fabrication of multilayer structure solar cell from solution-processing method. This unique temperature-dependent solubility of poly(2,5-bis(3-alkylthiophen-2-yl)thieno[3,2-b]thiophene) (PBTTT) enabled to spin-coat a solution of PBTTT at $70^{\circ} \mathrm{C}$ and another overlaid polymer (MDMO-PPV) from the same solvent at room temperature without dissolving the underlying PBTTT layer. As a result, the fabrication of multilayer BHJ solar cells from all-solution process was achieved. Postannealed bilayer bulk-heterojunction devices yielded a $V_{\text {oc }}$ of $0.59 \mathrm{~V}, J_{\text {sc }}$ values of $10.1-10.7 \mathrm{~mA} / \mathrm{cm}^{2}, \mathrm{FF}$ of 0.55 , and PCE of $3.0-3.2 \%$, showing an increased $J_{\mathrm{sc}}$ and PCE by a factor of 2 with respect to their single layer counterparts. Preparation of multilayer device from solution processing is difficult task because the underlying polymer layer may dissolve from the solution processing of the second polymeric solution. The follow-up work by Nakamura et al. demonstrates the fabrication of multilayer structure BHJ solar cell from lamination process $[37,53]$. Multilayer structures consisting of two blend layers of poly(3-hexylthiophene):(6,6)-phenyl C61 butyric acid methyl ester (P3HT:PCBM) and poly\{N-[1-(2'-ethylhexyl)-3-ethylheptanyl]-dithieno[3,2-b:2', 3' -d] pyrrole-2,6-diyl-alt-4,7-di(2thienyl)-2,1,3-benzothiadiazole- $5^{\prime}, 5^{\prime \prime}$-diyl $\}$ (PDTPDTBT): PCBM were prepared by a simple thermal lamination technique under heat and pressure [37]. They demonstrated improvement in PCE of inverted-structure laminated photovoltaic devices from $1.6 \%$ to $2.6 \%$ based on single structural BHJ solar cell. The insertion of a PEDOT:PSS layer, between the metal electrode and polymer layer, further improved the PCE to $3.3 \%$. However, lamination of two parts of the device to finish the final OPV structure was shown a decade ago for polymer-polymer bilayers [54].

Heat and pressure are important parameters to laminate two different electrodes. Nakamura et al. suggested that adhesive materials were not necessary when heat and pressure were applied simultaneously [37, 53]. However, Bailey et al. noticed that $25 \%$ of devices without adhesive material delaminated when plates of the press were pull apart [39]. Conducting polymers like d-sorbitol are mixed with PEDOT:PSS to improve adhesive property. D-sorbitol is a transparent glue, exhibiting a conductivity of $10^{2} \mathrm{Scm}^{-1}$ that could effectively laminate various substrates electrically and mechanically. D-sorbitol melts and penetrates into 
the polymer at temperature above $98-100^{\circ} \mathrm{C}[40]$. Bailey et al. selected flexible conducting substrate (PET) as anode to fabricate laminated solar cell with PET/Ag/PEDOT:PSS (dsorbitol)//P3HT:PCBM/ZnO/ITO/glass configuration. The PET substrates improve device reproducibility because of its flexible nature. Nonflexible glass substrate may break with pressure during lamination. The best-laminated device shows PCE of $3.19 \%$, which is higher than the control devices produced with the best-evaporated top metal electrode. Such improvement comes from the increased work function of Ag metal electrode with air oxidation [39]. Similarly, Yuan et al. [38] increases the work function of $\mathrm{Ag}$ film by ultraviolet/ozone treatment for improved photovoltaic response. This treatment increases the coverage of the adhesive material (d-sorbitol) from $70 \%$ to 100\%. The device architecture was PET/Ag/d-sorbitol// P3HT:PCBM/Cs $\mathrm{Co}_{3} / \mathrm{ITO} /$ glass. Hot plate lamination technique also promotes the crystallization of PCBM material [38]. Under the one-sun simulated irradiation, the device with laminated PET/Ag/d-sorbitol anode shows the highest PCE compared to devices without Ag electrodes. The reduction of device performance in PET/ITO/d-sorbitol architecture is believed to be due to (a) the increase in sheet resistance of ITO substrates during multiple bending and (b) penetration of ITO fragments into the soft polymer layers during the lamination process that may form current leakage paths. Similarly, improvements in device performance with $\mathrm{PEN} / \mathrm{Ag} / \mathrm{d}$-sorbitol anode have been explained as (a) better light harvest from the light reflection from top $\mathrm{Ag}$ anode film and (b) efficient charge collection, and (c) oxidation of Ag surface increases the anode work function and surface energy.

\section{Solid-State Dye-Sensitized Solar Cell Using Conjugated Polymers as HTMs}

Materials and technique that are used to fabricate inverted and laminated OPVs are almost same and similar to the materials and technique used to fabricate solid-state DSSCs that use conjugated polymers as HTMs. The prime differences are the sensitization of the $\mathrm{ZnO}$ or $\mathrm{TiO}_{2}$ layers, its thickness, and role of the compact layer. Organic material like spiroOMeTAD possesses higher PCE in solid-state DSSCs family [55]. But spiro-OMeTAD has low hole mobility and high fabrication cost compared to the conjugated organic polymer materials. Therefore, p-type conjugated polymer materials are one of the promising materials in this case [56-58]. External quantum efficiency (EQE) shows the large contribution of photocurrent generation from the sensitized layer [59-85]. Short circuit condition requires the electron injection from the excited dye molecule into conduction band of $\mathrm{TiO}_{2}$ and transfer of the hole through polymer layer to the back contact electrode. For this, several requirements have to be fulfilled [59]. They are as follows.

(a) The p-type polymeric material must be highly transparent in the spectral range, where the dye absorbs light. (b) p-type polymeric material must be available for depositing without dissolving or degrading the dye monolayer on $\mathrm{TiO}_{2}$ nanocrystallites.

(c) The excited state energy level of dye should be located above the conduction band of $\mathrm{TiO}_{2}$, and the ground state must be below the upper edge of the valence band of the p-type polymeric material. This is essential for electron transfer from the excited dye molecule to the conduction band of $\mathrm{TiO}_{2}$ and hole transfer to the valence band of the p-type polymeric material.

Various triarylamine-based polymers [60-63], poly(3alkylthiophene)s [64-76], polypyrrole [77-80], polyaniline [81-85], are studied as HTMs in solid-state DSSCs. The polymers cast from solutions must penetrate into the pores between the nanoparticles and should form a good contact with the absorbed dye. Karthikeyan et al. [86] demonstrated the self-organized interacted molecular between the dye and polymer layers, for the efficient transfer of hole from excited dye to polymer material. Actually, they developed ruthenium complexes carrying different triphenylamine-based donor groups, which combine with a triarylamine material of spiroOMeTAD. The result indicated that the dye/spiro-OMeTAD interfaces are self-organized by oleophilic interaction resulting in improved photocurrent and efficiency. Similarly, Jiang et al. [74] also reported the dyes with oleophilic thienyl groups, which show power conversion efficiency of up to $2.7 \%$. Such improvement in PCE is also believed because of self-organized interface between dye molecules and polymer material.

\section{Laminated Solid-State Dye-Sensitized Solar Cell}

In the previous section, it was noticed that lamination as a method of device fabrication has several advantages over conventional metal evaporation method. Therefore, we tried to fabricate solid-state DSSC from hot plate lamination technique. Poly(3-hexylthiophene) (P3HT) was spin coated on the surface of dye sensitized $\mathrm{TiO}_{2}$ layer. Likewise, in flexible ITO substrate, mix solution of poly(3,4-ethylenedioxythiophene) poly(styrenesulfonate) (PEDOT:PSS) and dsorbitol was spin coated. The two different electrodes were then pressed one above another on hot plate and laminated under heat and pressure. The performance of the device improves using flexible Au-coated ITO substrate.

5.1. Experimental Details. FTO substrates were cleaned with acetone, methanol followed by drying in nitrogen gas. It is then ozone treated for $10 \mathrm{mins}$, to remove remaining organic materials from the substrates. A compact layer of $\mathrm{TiO}_{x}$ paste (PASOL HPW-18NR) was spin coated on the cleaned FTO substrate at $2200 \mathrm{rpm}$ for $40 \mathrm{secs}$. This compact layer removes the possibility of short in the device. In this $\mathrm{FTO}^{-\mathrm{TiO}}{ }_{x}$ compact layer, nanoporous $\mathrm{TiO}_{2}$ slurry was spin coated to make $\mathrm{TiO}_{2}$ layer of about $2 \mu \mathrm{m}$ thickness. 


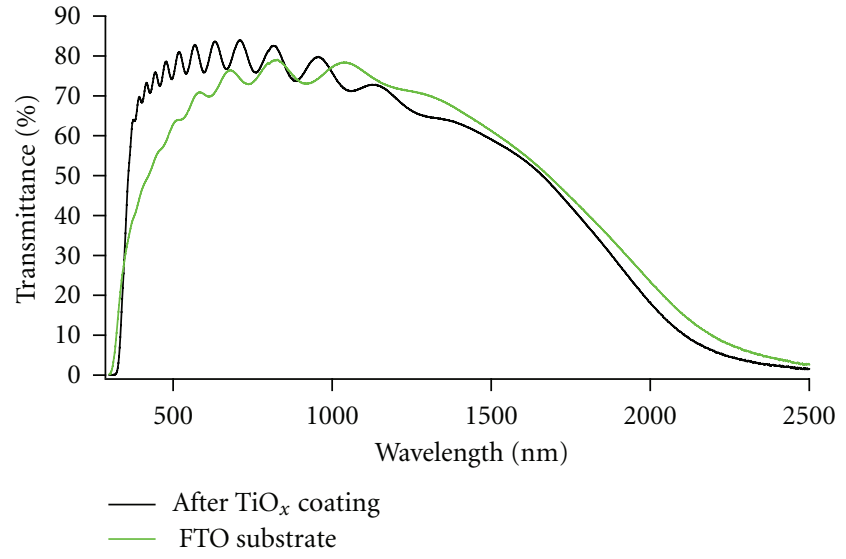

FIgure 2: Optical transmission spectra of FTO (red line) and $\mathrm{TiO}_{x}$ coated FTO substrate (black line). Commercially available $\mathrm{TiO}_{x}$ solution (PASOL HPW-18NR) was spin coated.

5.1.1. Preparation of $\mathrm{TiO}_{2}$ Slurry. $\mathrm{TiO}_{2}$ slurry is prepared in the following way. At first, $4 \mathrm{mg}$ of P25 $\mathrm{TiO}_{2}$ nanoparticles was mixed with $0.4 \mathrm{~mL}$ acetylacetone (2,4-Pentanedione) and ground for a few minutes till it changes to light golden color. In the second step, deionized water $(0.5 \mathrm{~mL})$ was poured on it and ground for 5 minutes. At every 5 minutes, the same amount of deionized water $(0.5 \mathrm{~mL})$ was added and ground. This process was repeated for 7 times then $2 \mathrm{~mL}$ of TritonX (30 vol\%) was mixed on the solution. Finally, fine PEG $(0.4 \mathrm{mg})$ was added to the $\mathrm{TiO}_{2}$ slurry and ground for a few minutes (10 minutes). The prepared $\mathrm{TiO}_{2}$ paste was spin coated on the surface of $\mathrm{FTO}-\mathrm{TiO}_{x}$ compact layer.

5.1.2. Device Fabrication. The above substrates were sintered at $450^{\circ} \mathrm{C}$ for $30 \mathrm{~min}$ and sensitized with Ru-dye (N719) for 18 hours in ethanol solution. P3HT $(17 \mathrm{mg} / \mathrm{mL})$ solution in 1,2-dichlorobenzene was spin coated on the surface of dye-sensitized $\mathrm{TiO}_{2}$ layer at $2000 \mathrm{rpm}$ for $40 \mathrm{sec}$. This completes the fabrication of one (bottom electrode) part of the laminated solid-state DSSC. Another part (top electrode) was prepared in flexible ITO plastic substrate (with and without $\mathrm{Au}$ deposition) by spin coating PEDOT:PSS (with $10 \mathrm{wt} \%$ of D-sorbitol) at $500 \mathrm{rpm}$ for $30 \mathrm{sec}$. Finally, the two parts of the device were placed one above another at hot plates and laminated under heat $\left(120^{\circ} \mathrm{C}\right)$ and pressure (1.2 Mpa) in air. Before lamination, the edges of the FTO substrates were covered with plastic tape so that the cracked or bare spaces at the edges do not touch the upper electrode.

5.1.3. Characterization. Surface morphologies of $\mathrm{TiO}_{2}$ films were studied using SEM (Hitachi S-3000H). The currentvoltage $(\mathrm{J}-\mathrm{V})$ characteristics of the devices were measured by a JASCO instrument with a white light xenon lamp under one-sun illumination (AM1.5 G, $100 \mathrm{~mW} / \mathrm{cm}^{2}$ ). All characterizations were carried out in an ambient environment. Ultraviolet/visible/near infrared (UV/VIS/NIR) spectrophotometry was taken from JASCO V-570. Atomic force

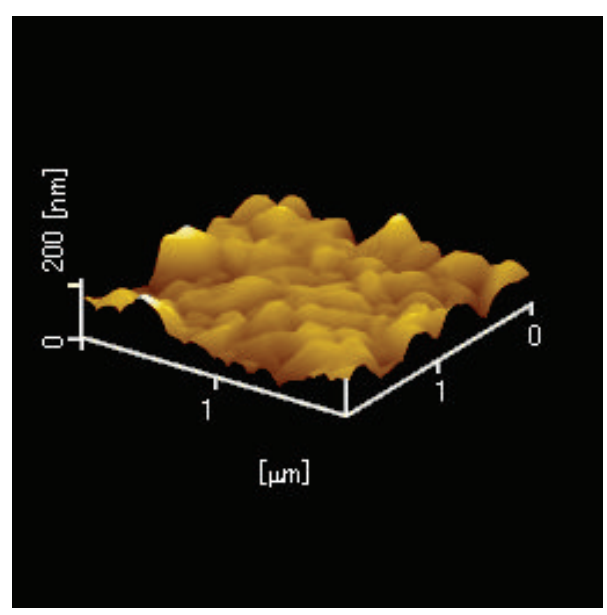

(a)

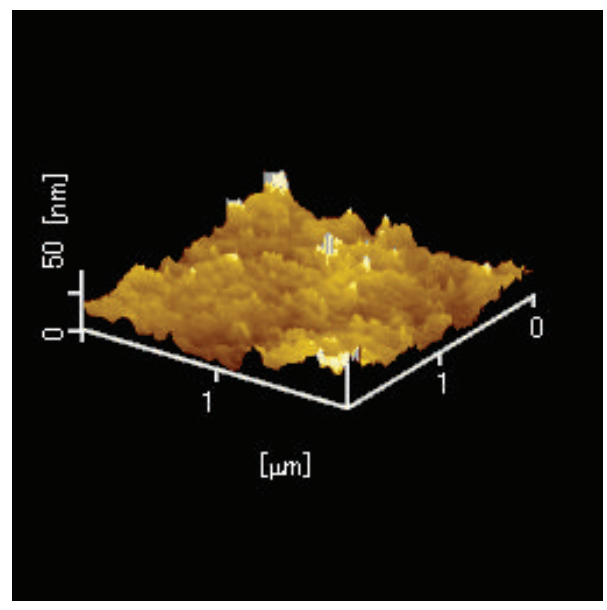

(b)

Figure 3: AFM images of FTO before (a) and after (b) $\mathrm{TiO}_{x}$ coating.

microscopy (AFM) images were obtained by Spa 300 SII Seiko Instrument.

\subsection{Results and Discussion}

5.2.1. Improvement in Transparency after $\mathrm{TiO}_{x}$ Coating. Figure 2 shows the improvement in transparency of FTO substrates from $400 \mathrm{~nm}$ to $750 \mathrm{~nm}$ wavelength after spin coating of $\mathrm{TiO}_{x}$ solution. The reason for this transmission improvement is unknown at present condition because of the lack of chemical compositions of the commercial product (PASOL HPW-18NR).

Figures 3(a) and 3(b) show the AFM images of FTO glass substrate before and after spin coating of $\mathrm{TiO}_{x}$ solution, respectively. It depicts that the RMS roughness of FTO substrates reduced from $3.060 E+01 \mathrm{~nm}$ to $8.317 \mathrm{~nm}$ and the peak-to-valley $(\mathrm{P}-\mathrm{V})$ distance was also reduced from $2.233 E+02 \mathrm{~nm}$ to $7.776 E+01 \mathrm{~nm}$. This measurement indicates that the roughness and $\mathrm{P}-\mathrm{V}$ distance improve after $\mathrm{TiO}_{x}$ coating. 


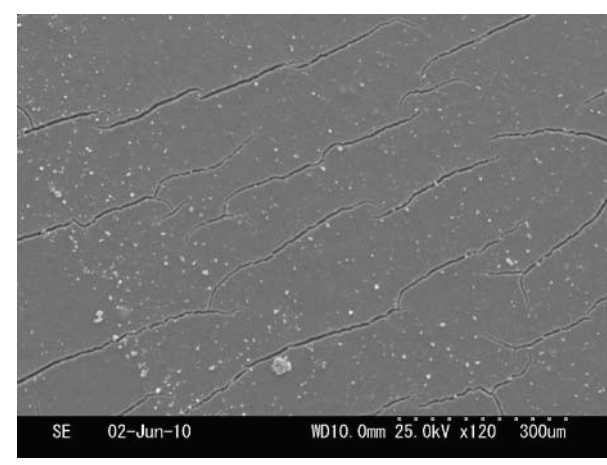

(a)

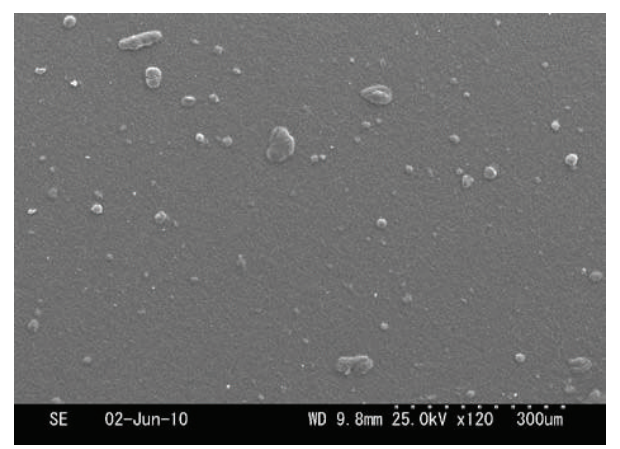

(b)

FIgURE 4: SEM images show (a) cracks on $\mathrm{TiO}_{2}$ film and (b) crackfree $\mathrm{TiO}_{2}$ film after mixing with commercial $\mathrm{TiO}_{x}$ paste.

5.2.2. Surface Morphology of $\mathrm{TiO}_{2}$ Films. Figure 4(a) shows the SEM image of the $\mathrm{TiO}_{2}$ film $\left(\right.$ not $\mathrm{TiO}_{x}$ ) on FTO substrate. After sintering, cracks were observed in the film. With liquid electrolyte, DSSC works well even though the conducting FTO substrate is in direct contact with the electrolyte at the FTO/electrolyte interface. But for solid-state DSSC, this becomes the problem. Crack-free titanium layer was prepared by mixing the same amount of commercial available titanium paste (Pasol-HPW-18NR) with our prepared paste with $1: 1$ ratio. Thin film produced from the mixed slurry lacks cracks after sintering as shown in Figure 4(b).

\subsubsection{Device Characterization and Discussion. Figure 5(a)} shows the device configuration of solid-state DSSC fabricated from hot press lamination. The melting point of $\mathrm{d}$ sorbitol is about $90 \sim 100^{\circ} \mathrm{C}$. After reaching to its melting point, it laminates two electrodes electrically and mechanically. Its solvent-free electric glue exhibits a conductivity of $10^{2} \mathrm{~S} / \mathrm{cm} \mathrm{[40].} \mathrm{Figure} \mathrm{5(b)} \mathrm{shows} \mathrm{the} \mathrm{photograph} \mathrm{of} \mathrm{the}$ laminated PET/ITO/PEDOT:PSS (d-sorbitol)//P3HT/N719$\mathrm{TiO}_{2} / \mathrm{TiO}_{x} / \mathrm{FTO} /$ glass substrate (the // represents the laminated interfaces), photovoltaic device. The device fabricated without d-sorbitol does not show adhesive property.

Figure 6 shows the J-V characteristics of the photovoltaic devices measured under AM 1.5 simulated solar radiations. The cells were prepared with and without Au-deposited ITOPET substrate. The mask of area $0.16 \mathrm{~cm}^{2}$ was used during $120^{\circ} \mathrm{C}+1.2 \mathrm{MPa}$

\begin{tabular}{|c|c|}
\hline \multicolumn{2}{|c|}{ PET } \\
\hline ITO \\
\hline PEDOT:PSS + D-sorbitol \\
\hline
\end{tabular}

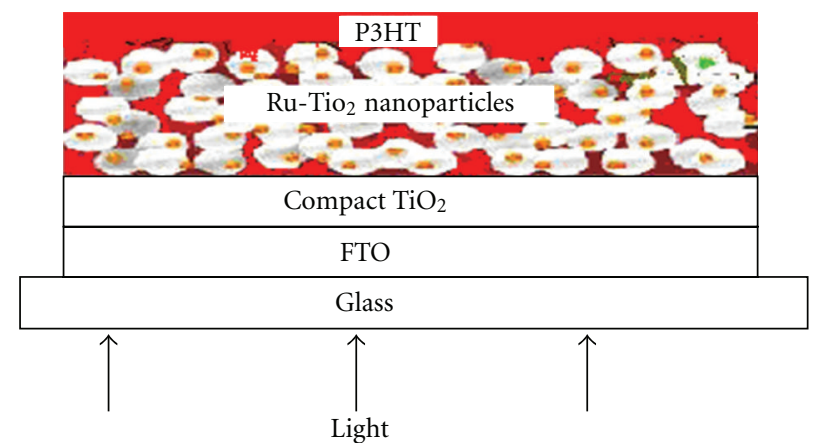

(a)

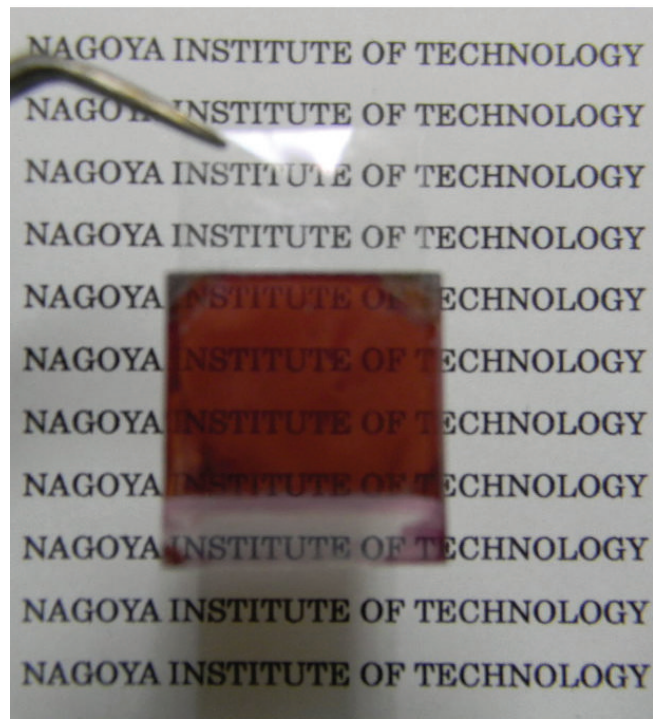

(b)

FIGURE 5: (a) Schematic of the PET/ITO/PEDOT:PSS:d-sorbitol//P3HT/Ru- $\mathrm{TiO}_{2} / \mathrm{TiO}_{x} / \mathrm{FTO} /$ glass heterojunction solar cell where // represents laminated interface. (b) Photograph of laminated heterojunction solar cell fabricated by hot plate lamination.

$J-V$ measurement. Under illumination, Au-deposited ITOPET device shows $J_{\text {sc }}$ and $V_{\text {oc }}$ about $0.031 \mathrm{~mA} / \mathrm{cm}^{2}$ and $0.122 \mathrm{~V}$, respectively. The fill factor (FF) and white light conversion efficiency $(\eta)$ are about 0.272 and $0.001 \%$, respectively. A twin reference cell fabricated on identical parameters with ITO-PET substrate shows no good photovoltaic response. We believe that such improvement in photovoltaic properties is due to excess light harvest from light reflection through top metal electrode and good contact between metal electrode and polymer layer. In bare ITO substrate, it may be possible that ITO fragments penetrate the soft polymer layer during the lamination process that may form current 


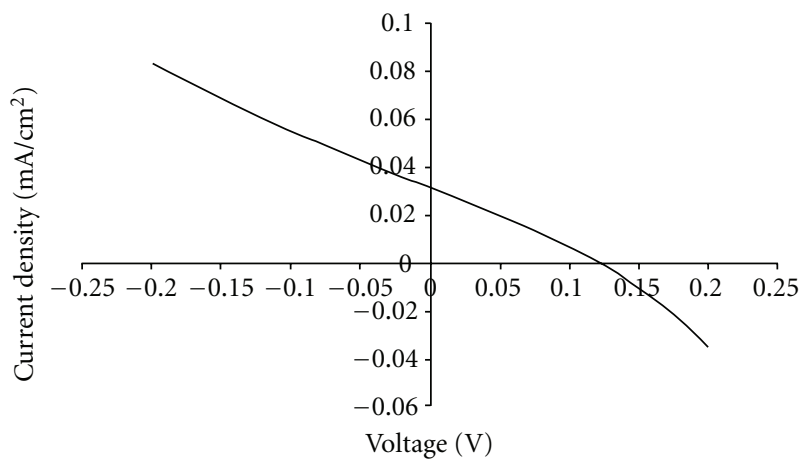

Figure 6: Current voltage $(\mathrm{J}-\mathrm{V})$ characteristic of the laminated heterojunction solar cell under AM 1.5 simulated solar radiation.

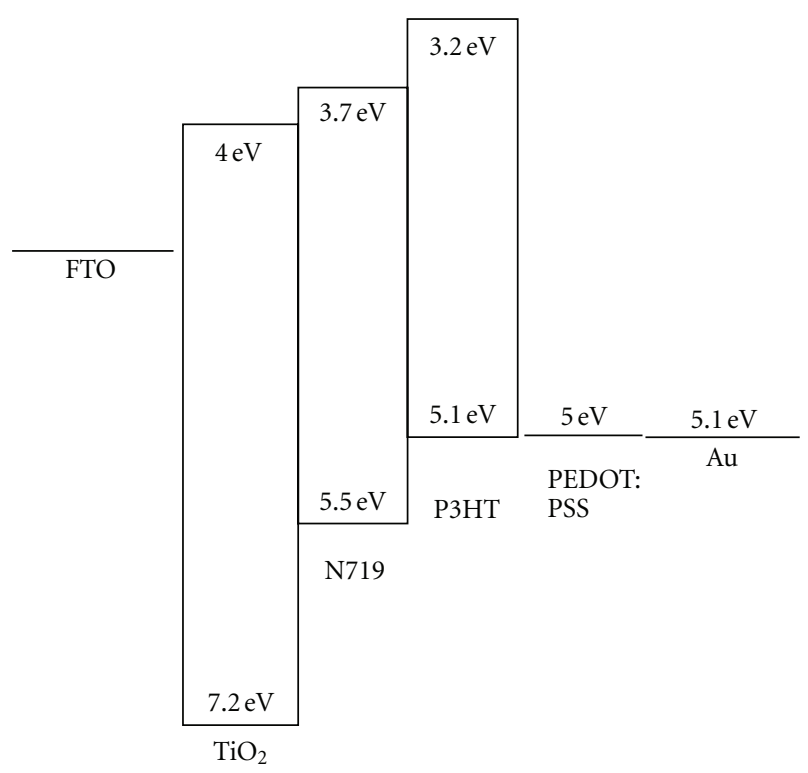

FIGURE 7: Energy band diagram of the fabricated device showing band alignment.

leakage path. The photovoltaic properties that are stated here are just a report on the successful fabrication of solidstate DSSCs from hot plate lamination method. There is a lot of scope to optimize the device parameters for the improved photovoltaic properties. Sensitizing $\mathrm{TiO}_{2}$ particles with dye of high molar extinction coefficient, optimization of parameters, improving crystallinity of polymer materials, and incorporating quantum dots and carbon nanomaterials with polymer or $\mathrm{TiO}_{2}$ particles are some of the simple ways to improve the device performance. The control device parameters will be discussed on separate communication.

Generally, p-type semiconducting polymers that accept holes from the dye cation are important. In $\mathrm{FTO} / \mathrm{TiO}_{x} / \mathrm{N} 719$ $\mathrm{TiO}_{2} / \mathrm{P} 3 \mathrm{HT} / / \mathrm{PEDOT}$ :PSS (d-sorbitol)/Au/ITO/PET configuration, we believe that photoexcited dye molecules inject electrons into the conduction band of $\mathrm{TiO}_{2}\left(E_{\mathrm{cb}} \sim 4 \mathrm{eV}\right)$ and hole towards P3HT. The favorable charge transportation is suitable because the excited state energy level of N719
(LUMO $\sim 3.7 \mathrm{eV})$ is located above the conduction band of $\mathrm{TiO}_{2}$, and the ground state (HOMO $\sim 5.5 \mathrm{eV}$ ) level is below the upper edge of the valance band of the P3HT $\left(E_{\mathrm{vb}} \sim 5.1 \mathrm{eV}\right)$. This is essential for electron transfer from the excited dye molecule to the conduction band of $\mathrm{TiO}_{2}$ and hole transfer to the valance band of P3HT. P3HT possesses high hole mobility of up to $0.1 \mathrm{~cm}^{2} \mathrm{~V}^{-1} \mathrm{~s}^{-1}$. Energetically favorable charge transportation and band diagram are shown in Figure 7.

\section{Conclusion}

Inverted organic solar cell architecture allows depositing various layers of material onto flexible substrates from solution processing to industrial roll-to-roll manufacture. This device architecture is further modified by depositing, optimizing, and characterizing two parts of the organic layers independently in laminated organic solar cell. The power conversion capacities of inverted and laminated solar cells are almost same or higher to the power conversion efficiency of devices fabricated from conventional process. More interestingly, the device architecture of inverted solar cells is similar to the device architecture of solid-state DSSCs that use conjugated polymer as HTMs, which make it possible for the fabrication of laminated solid-state DSSCs. Fabrication of solid-state DSSC from hot plate lamination is simple and cost-effective method. The present studies offer novel directions for achieving high-efficiency solid-state DSSCs by optimizing and characterizing two different parts of the device independently before bringing them to contact.

\section{Acknowledgment}

I. Khatri would like to thank Kosuke Ezaka for his kind cooperation and support.

\section{References}

[1] J. Y. Kim, S. H. Kim, H.-H. Lee et al., "New architecture for high-efficiency polymer photovoltaic cells using solutionbased titanium oxide as an optical spacer," Advanced Materials, vol. 18, pp. 572-576, 2006.

[2] A. Yakimov and S. R. Forrest, "High photovoltage multipleheterojunction organic solar cells incorporating interfacial metallic nanoclusters," Applied Physics Letters, vol. 80, no. 9, pp. 1667-1669, 2002.

[3] P. W. M. Blom, V. D. Mihailetchi, L. J. A. Koster, and D. E. Markov, "Device physics of polymer:Fullerene bulk heterojunction solar cells," Advanced Materials, vol. 19, no. 12, pp. 1551-1566, 2007.

[4] R. F. Service, "Outlook brightens for plastic solar cells," Science, vol. 332, no. 6027, p. 293, 2011.

[5] G. Dennler, M. C. Scharber, T. Ameri et al., "Design rules for donors in bulk-heterojunction tandem solar cells-towards 15 $\%$ energy-conversion efficiency," Advanced Materials, vol. 20, no. 3, pp. 579-583, 2008.

[6] G. Li, C.-W. Chu, V. Shrotriya, J. Huang, and Y. Yang, "Efficient inverted polymer solar cells," Applied Physics Letters, vol. 88, no. 25, Article ID 253503, 2006. 
[7] C. H. Hsieh, Y. J. Cheng, P. J. Li et al., "Highly efficient and stable inverted polymer solar cells integrated with a cross-linked fullerene material as an interlayer," Journal of the American Chemical Society, vol. 132, no. 13, pp. 4887-4893, 2010.

[8] M. Glatthaar, M. Niggemann, B. Zimmermann et al., "Organic solar cells using inverted layer sequence," Thin Solid Films, vol. 491, no. 1-2, pp. 298-300, 2005.

[9] D. W. Zhao, P. Liu, X. W. Sun, S. T. Tan, L. Ke, and A. K. K. Kyaw, "An inverted organic solar cell with an ultrathin Ca electron-transporting layer and $\mathrm{MoO}_{\mathrm{O}}$ hole-transporting layer," Applied Physics Letters, vol. 95, Article ID 153304, 2009.

[10] F. C. Krebs, "Air stable polymer photovoltaics based on a process free from vacuum steps and fullerenes," Solar Energy Materials and Solar Cells, vol. 92, no. 7, pp. 715-726, 2008.

[11] W. Gaynor, J. Y. Lee, and P. Peumans, "Fully solution-processed inverted polymer solar cells with laminated nanowire electrodes," ACS Nano, vol. 4, no. 1, pp. 30-34, 2010.

[12] C. Girotto, B. P. Rand, S. Steudel, J. Genoe, and P. Heremans, "Nanoparticle-based, spray-coated silver top contacts for efficient polymer solar cells," Organic Electronics, vol. 10, no. 4, pp. 735-740, 2009.

[13] S. K. Hau, H. L. Yip, K. Leong, and A. K. Y. Jen, "Spraycoating of silver nanoparticle electrodes for inverted polymer solar cells," Organic Electronics, vol. 10, no. 4, pp. 719-723, 2009.

[14] M. S. White, D. C. Olson, S. E. Shaheen, N. Kopidakis, and D. S. Ginley, "Inverted bulk-heterojunction organic photovoltaic device using a solution-derived $\mathrm{ZnO}$ underlayer," Applied Physics Letters, vol. 89, no. 14, Article ID 143517, 2006.

[15] S. K. Hau, H.-L. Yip, H. Ma, and A. K.-Y. Jen, "High performance ambient processed inverted polymer solar cells through interfacial modification with a fullerene self-assembled monolayer," Applied Physics Letters, vol. 93, no. 23, Article ID 233304, 2008.

[16] C. Waldauf, M. Morana, P. Denk et al., "Highly efficient inverted organic photovoltaics using solution based titanium oxide as electron selective contact," Applied Physics Letters, vol. 89, no. 23, Article ID 233517, 2006.

[17] R. Steim, S. A. Choulis, P. Schilinsky, and C. J. Brabec, "Interface modification for highly efficient organic photovoltaics," Applied Physics Letters, vol. 92, no. 9, Article ID 093303, 2008.

[18] S. K. Hau, H. L. Yip, O. Acton, N. S. Baek, H. Ma, and A. K. Y. Jen, "Interfacial modification to improve inverted polymer solar cells," Journal of Materials Chemistry, vol. 18, no. 42, pp. 5113-5119, 2008.

[19] H.-H. Liao, L.-M. Chen, Z. Xu, G. Li, and Y. Yang, "Highly efficient inverted polymer solar cell by low temperature annealing of Cs2 C O3 interlayer," Applied Physics Letters, vol. 92, Article ID 173303, 2008.

[20] Y. I. Lee, J. H. Youn, M. S. Ryu, J. Kim, H. T. Moon, and J. Jang, "Highly efficient inverted poly(3-hexylthiophene): methanofullerene [6,6]-phenyl C71-butyric acid methyl ester bulk heterojunction solar cell with $\mathrm{Cs} 2 \mathrm{CO} 3$ and MoO3," Organic Electronics, vol. 12, no. 2, pp. 353-357, 2011.

[21] D. W. Zhao, S. T. Tan, L. Ke et al., "Optimization of an inverted organic solar cell," Solar Energy Materials and Solar Cells, vol. 94, no. 6, pp. 985-991, 2010.

[22] T. Hori, H. Moritou, N. Fukuoka, J. Sakamoto, A. Fujii, and M. Ozaki, "Photovoltaic properties in interpenetrating heterojunction organic solar cells utilizing $\mathrm{MoO} 3$ and $\mathrm{ZnO}$ charge transport buffer layers," Materials, vol. 3, pp. 4915-4921, 2010.

[23] T. Hori, T. Shibata, V. Kittichungchit et al., "MoO3 buffer layer effect on photovoltaic properties of interpenetrating heterojunction type organic solar cells," Thin Solid Films, vol. 518 , no. 2, pp. 522-525, 2009.
[24] A. K. K. Kyaw, X. W. Sun, C. Y. Jiang, G. Q. Lo, D. W. Zhao, and D. L. Kwong, "An inverted organic solar cell employing a sol-gel derived $\mathrm{ZnO}$ electron selective layer and thermal evaporated $\mathrm{MoO}_{3}$ hole selective layer," Applied Physics Letters, vol. 93, Article ID 221107, 2008.

[25] C. Tao, S. Ruan, X. Zhang et al., "Performance improvement of inverted polymer solar cells with different top electrodes by introducing a $\mathrm{MoO}_{3}$ buffer layer," Applied Physics Letters, vol. 93, Article ID 193307, 2008.

[26] H. Schmidt, H. Flügge, T. Winkler, T. Bülow, T. Riedl, and W. Kowalsky, "Efficient semitransparent inverted organic solar cells with indium tin oxide top electrode," Applied Physics Letters, vol. 94, Article ID 243302, 2009.

[27] V. Shrotriya, G. Li, Y. Yao, C.-W. Chu, and Y. Yang, "Transition metal oxides as the buffer layer for polymer photovoltaic cells," Applied Physics Letters, vol. 88, Article ID 073508, 2006.

[28] N. Espinosa, H. F. Dam, D. M. Tanenbaum, J. W. Andreasen, M. Jorgensen, and F. C. Krebs, "Roll-to-roll processing of inverted polymer solar cells using hydrated vanadium(V) oxide as a PEDOT:PSS replacement ", Materials, vol. 4, pp. 169-182, 2011.

[29] C. Tao, S. Ruan, G. Xie et al., "Role of tungsten oxide in inverted polymer solar cells," Applied Physics Letters, vol. 94, Article ID 043311, 2009.

[30] M. Y. Chan, C. S. Lee, S. L. Lai et al., "Efficient organic photovoltaic devices using a combination of exciton blocking layer and anodic buffer layer," Journal of Applied Physics, vol. 100, no. 9, Article ID 094506, 2006.

[31] S. K. Hau, H.-L. Yip, J. Zou, and A. K.-Y. Jen, "Indium tin oxide-free semi-transparent inverted polymer solar cells using conducting polymer as both bottom and top electrodes," Organic Electronics, vol. 10, no. 7, pp. 1401-1407, 2009.

[32] B.-Y. Yu, A. Tsai, S.-P. Tsai et al., "Efficient inverted solar cells using $\mathrm{TiO}_{2}$ nanotube arrays," Nanotechnology, vol. 19, no. 25, Article ID 255202, pp. 2552021-2552025, 2008.

[33] J. Weickert, H. Sun, C. Palumbiny, H. C. Hesse, and L. Schmidt-Mende, "Spray-deposited PEDOT: PSS for inverted organic solar cells," Solar Energy Materials and Solar Cells, vol. 94, no. 12, pp. 2371-2374, 2010.

[34] C. Y. Li, T. C. Wen, and T. F. Guo, "Sulfonated poly(diphenylamine) as a novel hole-collecting layer in polymer photovoltaic cells," Journal of Materials Chemistry, vol. 18, no. 37, pp. 4478-4482, 2008.

[35] F. C. Krebs, S. A. Gevorgyan, and J. Atstrup, "A roll-to-roll process to flexible polymer solar cells: model studies, manufacture and operational stability studies," Journal of Materials Chemistry, vol. 19, pp. 5442-5451, 2009.

[36] S. K. Hau, H. L. Yip, and A. K. Y. Jen, "A review on the development of the inverted polymer solar cell architecture," Polymer Reviews, vol. 50, no. 4, pp. 474-510, 2010.

[37] M. Nakamura, C. Yang, E. Zhou, K. Tajima, and K. Hashimoto, "Polymer bulk heterojunction photovoltaic devices with multilayer structures prepared by thermal lamination," ACS Applied Materials and Interfaces, vol. 1, no. 12, pp. 2703-2706, 2009.

[38] Y. Yuan, Y. Bi, and J. Huang, "Achieving high efficiency laminated polymer solar cell with interfacial modified metallic electrode and pressure induced crystallization," Applied Physics Letters, vol. 98, Article ID 063306, 2011.

[39] B. A. Bailey, M. O. Reese, D. C. Olson, S. E. Shaheen, and N. Kopidakis, "Air-processed organic photovoltaic devices fabricated with hot press lamination," Organic Electronics, vol. 12, no. 1, pp. 108-112, 2011. 
[40] J. Ouyang and Y. Yang, "Conducting polymer as transparent electric glue," Advanced Materials, vol. 18, no. 16, pp. 21412144, 2006.

[41] M. Jørgensen, K. Norrman, and F. C. Krebs, "Stability/degradation of polymer solar cells," Solar Energy Materials and Solar Cells, vol. 92, no. 7, pp. 686-714, 2008.

[42] K. Suemori, T. Miyata, M. Yokoyama, and M. Hiramoto, "Organic solar cells protected by very thick naphthalene tetracarboxylic anhydride films," Applied Physics Letters, vol. 85 , no. 25, pp. 6269-6271, 2004.

[43] K. Suemori, M. Yokoyama, and M. Hiramoto, "Electrical shorting of organic photovoltaic films resulting from metal migration," Journal of Applied Physics, vol. 99, Article ID 036109, 2006.

[44] T. H. Lee, J. C. A. Huang, G. L. Pakhomov et al., "Organicoxide cathode buffer layer in fabricating high-performance polymer light-emitting diodes," Advanced Functional Materials, vol. 18, no. 19, pp. 3036-3042, 2008.

[45] G. Gu, V. Bulovic, P. E. Burrows, S. R. Forrest, and N. E. Thompson, "Transparent organic light emitting devices," Applied Physics Letters, vol. 68, pp. 2606-2608, 1996.

[46] H.-K. Kim, D.-G. Kim, K.-S. Lee et al., "Plasma damage-free sputtering of indium tin oxide cathode layers for top-emitting organic light-emitting diodes," Applied Physics Letters, vol. 86, no. 18, Article ID 183503, pp. 1-3, 2005.

[47] K. H. Yim, Z. Zheng, Z. Liang, R. H. Friend, W. T. S. Huck, and J. S. Kim, "Efficient conjugated-polymer optoelectronic devices fabricated by thin-film transfer-printing technique," Advanced Functional Materials, vol. 18, no. 7, pp. 1012-1019, 2008.

[48] L. Chen, P. Degenaar, and D. D. C. Bradley, "Polymer transfer printing: application to layer coating, pattern definition, and diode dark current blocking," Advanced Materials, vol. 20, no. 9, pp. 1679-1683, 2008.

[49] J. H. Huang, Z. Y. Ho, T. H. Kuo, D. Kekuda, C. W. Chu, and K. C. Ho, "Fabrication of multilayer organic solar cells through a stamping technique," Journal of Materials Chemistry, vol. 19, no. 24, pp. 4077-4080, 2009.

[50] D. H. Wang, D. G. Choi, K. J. Lee, S. H. Im, O. O. Park, and J. H. Park, "Unexpected solid-solid intermixing in a bilayer of poly(3-hexylthiophene) and [6,6]-phenyl C61-butyric acidmethyl ester via stamping transfer," Organic Electronics, vol. 11, no. 8, pp. 1376-1380, 2010.

[51] D. H. Wang, D. G. Choi, K. J. Lee, O. O. Park, and J. H. Park, "Photovoltaic devices with an active layer from a stamping transfer technique: single layer versus double layer," Langmuir, vol. 26, no. 12, pp. 9584-9588, 2010.

[52] Q. Sun, K. Park, and L. Dai, "Liquid crystalline polymers for efficient bilayer-bulk-heterojunction solar cells," Journal of Physical Chemistry C, vol. 113, no. 18, pp. 7892-7897, 2009.

[53] M. Nakamura, C. Yang, K. Tajima, and K. Hashimoto, "Highperformance polymer photovoltaic devices with inverted structure prepared by thermal lamination," Solar Energy Materials and Solar Cells, vol. 93, no. 9, pp. 1681-1684, 2009.

[54] M. Granström, K. Petritsch, A. C. Arias, A. Lux, M. R. Andersson, and R. H. Friend, "Laminated fabrication of polymeric photovoltaic diodes," Nature, vol. 395, no. 6699, pp. 257-260, 1998.

[55] U. Bach, D. Lupo, P. Comte et al., "Solid-state dye-sensitized mesoporous $\mathrm{TiO}_{2}$ solar cells with high photon-to-electron conversion efficiencies," Nature, vol. 395, no. 6702, pp. 583$585,1998$.

[56] T. J. Savenije, J. M. Warman, and A. Goossens, "Visible light sensitisation of titanium dioxide using a phenylene vinylene polymer," Chemical Physics Letters, vol. 287, no. 1-2, pp. 148153, 1998.

[57] A. C. Arango, S. A. Carter, and P. J. Brock, "Charge transfer in photovoltaics consisting of interpenetrating networks of conjugated polymer and $\mathrm{TiO}_{2}$ nanoparticles," Applied Physics Letters, vol. 74, no. 12, pp. 1698-1700, 1999.

[58] K. M. Coakley, Y. Liu, C. Goh, and M. D. McGehee, "Ordered organic-inorganic bulk heterojunction photovoltaic cells," Materials Research Society Bulletin, vol. 30, no. 1, pp. 37-40, 2005.

[59] D. Gebeyehu, C. J. Brabec, N. S. Sariciftci et al., "Hybrid solar cells based on dye-sensitized nanoporous $\mathrm{TiO}_{2}$ electrodes and conjugated polymers as hole transport materials," Synthetic Metals, vol. 125, no. 3, pp. 279-287, 2002.

[60] L. Schmidt-Mende and M. Grätzel, " $\mathrm{TiO}_{2}$ pore-filling and its effect on the efficiency of solid-state dye-sensitized solar cells," Thin Solid Films, vol. 500, no. 1-2, pp. 296-301, 2006.

[61] J. E. Kroeze, N. Hirata, and L. Schmidt-Mende, "Parameters influencing charge separation in solid-state dye-sensitized solar cells using novel hole conductors," Advanced Functional Materials, vol. 16, pp. 1832-1838, 2006.

[62] K. R. Haridas, J. Ostrauskaite, M. Thelakkat, M. Heim, R. Bilke, and D. Haarer, "Synthesis of low melting hole conductor systems based on triarylamines and application in dye sensitized solar cells," Synthetic Metals, vol. 121, no. 1-3, pp. 15731574, 2001.

[63] K. Peter, H. Wietasch, B. Peng, and M. Thelakkat, "Dualfunctional materials for interface modifications in solid-state dye-sensitised TiO2 solar cells," Applied Physics A, vol. 79, no. 1, pp. 65-71, 2004.

[64] J. Roncali, "Conjugated poly(thiophenes): synthesis, functionalization, and applications," Chemical Reviews, vol. 92, pp. 711-738, 1992.

[65] Y.-J. Cheng, S.-H. Yang, and C.-S. Hsu, "Synthesis of conjugated polymers for organic solar cell applications," Chemical Reviews, vol. 109, no. 11, pp. 5868-5923, 2009.

[66] C. Houarner-Rassin, E. Blart, P. Buvat, and F. Odobel, "Solidstate dye-sensitized $\mathrm{TiO}_{2}$ solar cells based on a sensitizer covalently wired to a hole conducting polymer," Photochemical and Photobiological Sciences, vol. 7, no. 7, pp. 789-793, 2008.

[67] N. Kudo, S. Honda, Y. Shimazaki, H. Ohkita, S. Ito, and H. Benten, "Improvement of charge injection efficiency in organic-inorganic hybrid solar cells by chemical modification of metal oxides with organic molecules," Applied Physics Letters, vol. 90, no. 18, Article ID 183513, 2007.

[68] C. Zafer, C. Karapire, N. S. Serdar, and S. Icli, "Characterization of N, N'-bis-2-(1-hydoxy-4-methylpentyl)-3, 4, 9, 10perylene bis (dicarboximide) sensitized nanocrystalline $\mathrm{TiO}_{2}$ solar cells with polythiophene hole conductors," Solar Energy Materials and Solar Cells, vol. 88, no. 1, pp. 11-21, 2005.

[69] M. Wang and X. Wang, " $\mathrm{P} 3 \mathrm{HT} / \mathrm{TiO}_{2}$ bulk-heterojunction solar cell sensitized by a perylene derivative," Solar Energy Materials and Solar Cells, vol. 91, no. 19, pp. 1782-1787, 2007.

[70] K. Takahashi, T. Nakanishi, T. Yamaguchi, J.-I. Nakamura, and K. Murata, "Performance enhancement by blending merocyanine photosensitizer in $\mathrm{TiO}_{2}$ /polythiophen solid-state solar cells," Chemistry Letters, vol. 34, no. 5, pp. 714-715, 2005.

[71] E. Lancelle-Beltran, P. Prené, C. Boscher, P. Belleville, P. Buvat, and C. Sanchez, "All-solid-state dye-sensitized nanoporous $\mathrm{TiO}_{2}$ hybrid solar cells with high energy-conversion efficiency," Advanced Materials, vol. 18, no. 19, pp. 2579-2582, 2006.

[72] R. Zhu, C. Y. Jiang, B. Liu, and S. Ramakrishna, "Highly efficient nanoporous $\mathrm{TiO}_{2}$-polythiophene hybrid solar cells 
based on interfacial modification using a metal-free organic dye," Advanced Materials, vol. 21, pp. 994-1000, 2009.

[73] J. Krüger, R. Plass, L. Cevey, M. Piccirelli, M. Grätzel, and U. Bach, "High efficiency solid-state photovoltaic device due to inhibition of interface charge recombination," Applied Physics Letters, vol. 79, pp. 2085-2087, 2001.

[74] K. J. Jiang, K. Manseki, Y. H. Yu et al., "Photovoltaics based on hybridization of effective dye-sensitized titanium oxide and hole-conductive polymer P3HT," Advanced Functional Materials, vol. 19, pp. 2481-2485, 2009.

[75] G. K. Mor, S. Kim, M. Paulose et al., "Visible to nearinfrared light harvesting in $\mathrm{TiO}_{2}$ nanotube array-P3HT based heterojunction solar cells," Nano Letters, vol. 9, pp. 4250-4257, 2009.

[76] J. A. Chang, J. H. Rhee, S. H. Im et al., "High-performance nanostructured inorganicâ-organic heterojunction solar cells," Nano Letters, vol. 10, no. 7, pp. 2609-2612, 2010.

[77] K. Murakoshi, R. Kogure, Y. Wada, and S. Yanagida, "Solid state dye-sensitized $\mathrm{TiO} 2$ solar cell with polypyrrole as hole transport layer," Chemistry Letters, no. 5, pp. 471-472, 1997.

[78] K. Murakoshi, R. Kogure, Y. Wada, and S. Yanagida, "Fabrication of solid-state dye-sensitized $\mathrm{TiO}_{2}$ solar cells combined with polypyrrole," Solar Energy Materials and Solar Cells, vol. 55, no. 1-2, pp. 113-125, 1998.

[79] T. Kitamura, M. Maitani, M. Matsuda, Y. Wada, and S. Yanagida, "Improved solid-state dye solar cells with polypyrrole using a carbon-based counter electrode," Chemistry Letters, no. 10, pp. 1054-1055, 2001.

[80] R. Cervini, Y. Cheng, and G. Simon, "Solid-state Ru-dye solar cells using polypyrrole as a hole conductor," Journal of Physics $D$, vol. 37, no. 1, pp. 13-20, 2004.

[81] S. X. Tan, J. Zhai, M. X. Wan, L. Jiang, and D. B. Zhu, "Polyaniline as a hole transport material to prepare solid solar cells," Synthetic Metals, vol. 137, no. 1-3, pp. 1511-1512, 2003.

[82] S. Tan, J. Zhai, B. Xue et al., "Property influence of polyanilines on photovoltaic behaviors of dye-sensitized solar cells," Langmuir, vol. 20, no. 7, pp. 2934-2937, 2004.

[83] S. Tan, J. Zhai, M. Wan et al., "Influence of small molecules in conducting polyaniline on the photovoltaic properties of solid-state dye-sensitized solar cells," Journal of Physical Chemistry B, vol. 108, no. 48, pp. 18693-18697, 2004.

[84] H. S. Kim and C. C. Wamser, "Photoelectropolymerization of aniline in a dye-sensitized solar cell," Photochemical and Photobiological Sciences, vol. 5, 955 pages, 2006.

[85] S. Ameen, M. S. Akhtar, G. S. Kim, Y. S. Kim, O. B. Yang, and H. S. Shin, "Plasma-enhanced polymerized aniline/ $/ \mathrm{TiO}_{2}$ dyesensitized solar cells," Journal of Alloys and Compounds, vol. 487, no. 1-2, pp. 382-386, 2009.

[86] C. S. Karthikeyan, H. Wietasch, and M. Thelakkat, "Highly efficient solid-state dye-sensitized $\mathrm{TiO}_{2}$ solar cells using donor-antenna dyes capable of multistep charge-transfer cascades," Advanced Materials, vol. 19, pp. 1091-1095, 2007. 

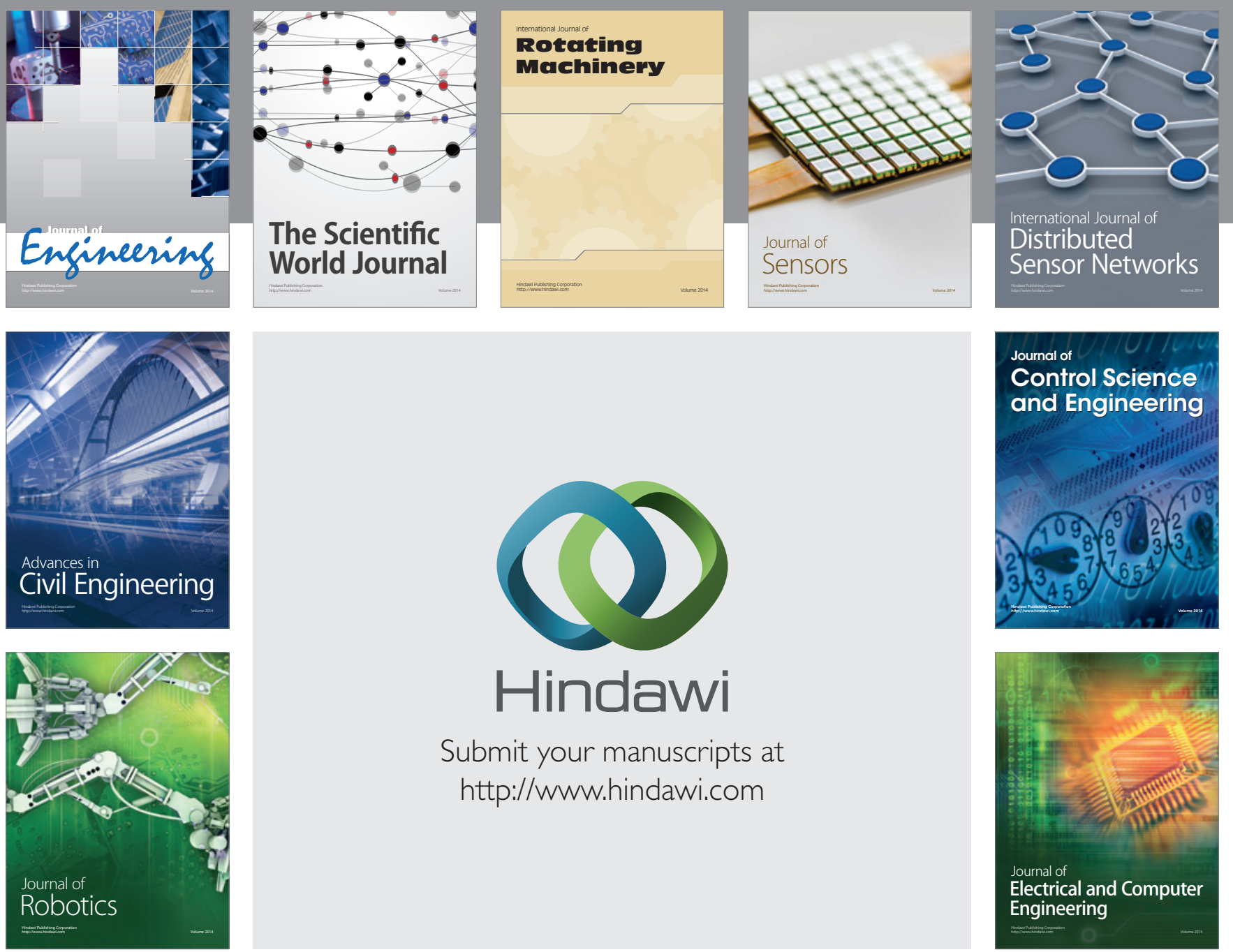

Submit your manuscripts at

http://www.hindawi.com
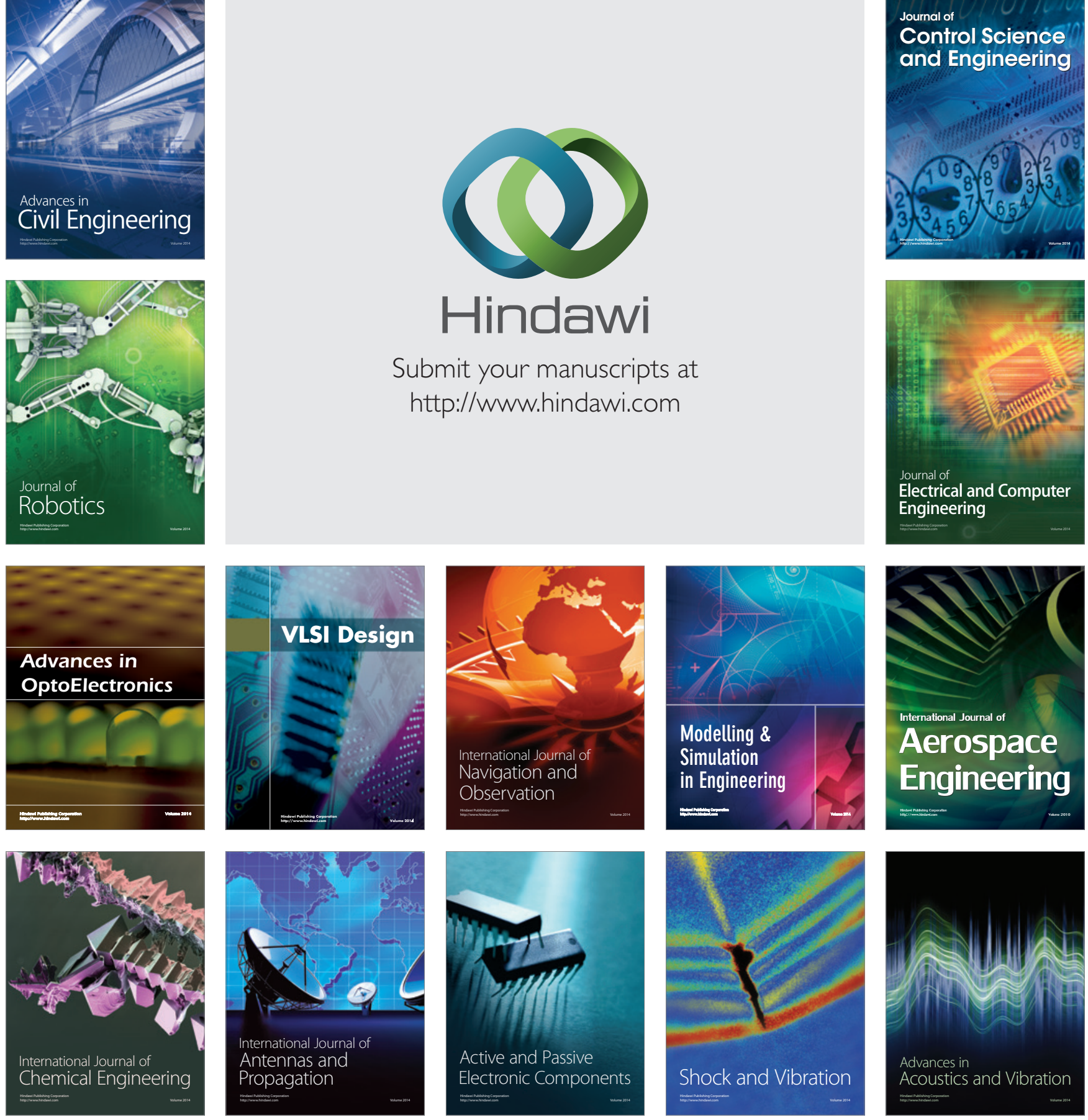